\title{
国際細菌命名規約とその周辺 (2)
}

\section{長谷川 武治}

日本微生物株保存連盟

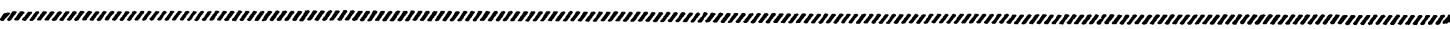

\section{7. 国際微生物学会議と国際細菌命名規約}

国際細菌命名視約の数次にわたる改正を進めてきたの は, 国際微生物学協会連合International Association of Microbiological Societies*である（以下，IAMS と略 称する.上記を含めて国際機関の日本名は，すべて日本 学術会議事務局編：国際学術団体総覧に従った. 1980 年 9 月, IAMS は名称を International Union of Microbiological Societies に変えた。 この名称変更は昇格を 意味するが，日本名はまだできていない，以下の記述は， すべて昇格前であることを断っておく)，IAMS は，国 際学術連合会議 International Council of Scientific Unions (ICSU) に所属する団体である. ICSUは 1931 年に設立され，その下部機構には，国際生物科学連合 International Union of Biological Sciences (IUBS), 国際純正・応用化学連合 International Union of Pure and Applied Chemistry (IUPAC) などがある. ICSU の活動は，各国政府ならびに各連合の分担金，UNESCO その他からの寄付金によって支えられている. IUBS が 設立されたのは，ICSUよりも早く，1919 年である. 生 物科学分野の研究その他の学術活動に和ける国際協力を 援助促進する目的で作られた機関で, 各国のアカデミ 一, 学術研究会議, 学協会, 委員会などが会員として加 入，46力国にわたる各国政府からの財政援助もある．植 物学, 動物学, 細胞・発生科学, 環境生物学, 微生物学 の 5 部会 Divisions, 生物史, 生物学教育, 生物測定を 含む学際部門 Interdisciplinary Commissions, 微生物 株保存, 微生物生態学, 生物系統進化学を含む複合部門

* 国際微生物学会協会のほ5が一般的である.“国際微生物学 協会連合”とい5日本語は, むしろこの組織体の新しい名称 である International Union of Microbiological Societies に適合している.
Multidisciplinary Commissions がそのなかに設けられ ている. IAMSは, IUBS の微生物学部会 Microbiology Division に直接所属し, 細菌学 Bacteriology, 菌学 Mycology，ウイルス学 Virology の各分科会 Sections と各種委員会 (Committee, Commission, Federation すなわち $\mathrm{COMCOF}$ を含む) を下部機構に持つ.

国際細菌命名規約に関する議決は，4年おきに開かれ る国際微生物学会議 (1973 年以降は国際細菌学会議) に おいて, IAMSが主催する総会で行なわれるそその決議 案の作成を担当するのは, 細菌学分科会 Bacteriology Sectionのなかに設けられている国際細菌分類命名委員 会 International Committee on Systematic Bacteriology (ICSB) である.ICSB は, 1970 年の IAMS 総 会で発足したが，それ以前の名称は国際細菌命名委員会 International Committee on Bacteriological Nomenclature (ICBN) であった. 1930 年，Parisで開催され た第 1 回国際微生物学会議以来, 毎回欠かさず出席し, この命名委員会 (ICBN) の歷史とともに歩み, 生涯 を細菌の学名問題に捧げたのは，米国の著名な細菌学 者, Robert E. Buchanan (1883〜1973)であった. 彼が R.S. Breed と協力して, Bergey's Manual of Determinative Bacteriology の編集に当ったのはよく知られて いる事実である. 1966 年に出版されたIndex Bergeyana は，その大部分が多年にわたる Buchanan の努力の結 晶である細菌学名カードによるもので，S.T. Cowan(国 際細菌命名規約 1976 年改正版) の言を借りるならこ の書は Index Buchananensis とするほうがむしろ当然 といらべきものであった.

命名委員会 (ICBN) の発足は第 1 回の Paris 会議であ った. 当初の委員長には， E. Pribramが選ばれて就任 した. 委員会は総員 8 名, るちろんのことBuchanan も 
そのひとりであったが，ほかに日本からの委員として山 崎何恵 (九州大学) の名が見られる. 第 1 回会議の決議 文には，要約すると，“微生物の命名は，国際植物命名 規約および国際動物命名規約に從うべきである，細菌は 特殊な取り扱いを必要とする生物群であるから，その命 名についてはこれを常置審議事項とする．細菌の分類と 命名のために，徽生物株保存機関の育成はきわめて重要 である.”と述べられており，これと同時に，ICBN の 2 名の常任幹事が国際植物学会議で細菌命名専門委員の 指名を受けた。

第 2 回国際微生物学会議は, 1936 年 London で開か れこれによって細菌の命名に関する暫定規約を作るた めの具体的計画がようやく進められることになった。す なわち，規約草案の起草委員会として，米国およびカナ ダの 7 委員からなるアメリカ小委員会 American Subcommittee が結成され，Buchanan は推されてその委 員長になった. アメリカ小委員会による命名規約試案 は，1939年 New York で開催された第 3 回国際微生物 学会議におけるICBN に上程され，審議された.この会 議の結果, ICBN の機構に重要な变化が起こった。 それ はICBN の組織下に裁決機関として裁定委員会 Judicial Commission が設けられたことである. New York 会 議において, 命名委員会とその裁定委員会の職務が明文 化されることになったが，それらを略述すれば以下のと おりである.

\section{1） ICBN の職務}

a 、命名規約の成文化または変更に関して受理した勧 告を審理し，判定する.

b. 裁定委員会から提出された命名に関する公表見解 Opinions を審理し，公認する。

c．公式の微生物株保存機関を指定する.

d. 命名または分類に関して, 裁定委員会, その他各 委員会から提出された報告および勧告を処理する.

e 、命名上の共通な問題について, 国際植物学会議, 国際動物学会議その他の諸委員会と協力, 審議する.

2） ICBN 裁定委員会の職務

a 、命名規則の適用に疑議が生じた場合ここれに対し て公表見解を準備する.

b. 学名の保存, 廃棄および命名規則の改正に関して 公表見解を準備し，ICBN に提出する.

c. 属, 種その他, 分類階級の学名の基準に関する見
解をまとめ，属名リストを作成する，属名リストは 細菌だけでなく，他の微生物属に関する調查も行な って，違法なホモニム（巽物同名）を生じないよう に努める.

裁定委員会は 12 名の委員で構成され，Buchanan が その初代委員長に就任した，折から第二次世界大戦の勃 発で, 命名規約試案の検討は中断された.

第 4 回国際微生物学会議は, 戦後間もない 1947 年, Copenhagen で開かれた. Copenhagen 会議で懸案の命 名規約試案が検討修正された。裁定委員会, ICBN, IAMS 総会の承認を受けて英文テキスト〔Buchanan and Breed : J. Bacteriol., 55，287〜306 (1948)]がまず発表さ れ, つづいてスペイン語訳, ドイツ語訳, フランス語訳, 日本語訳 [小南 清: Nagaoa，3，101 122 (1953)] が 順次公表された.

第 5 回国際微生物学会議は, 1950 年に Rio de Janeiro で，第 6 回会議は，1953 年，Rome で行なわれた．この 両会議では，さきに発表された試案テキストに寄せられ たさまざまな批判や提案が詳細に審議され，その結論を 盛りこんで 1958 年, 国際細菌・ウイルス命名規約 International Code of Nomenclature of Bacteria and Viruses (186頁) が出版された. 各規則ごとに註釈がつ けられるといら，ゆきどいた配虑のある，この分野で は最初の本格的な命名規約で，まさに記念碑的価値があ る.これは，今回の改正規約に対して第 1 版として扱わ れている.

上記の命名規約はその後改正され，Moscow で開催さ れた第 9 回国際微生物学会議における総会で承認された のち，発表された，この規約は International Journal of Systematic Bacteriology (IJSB), 16, 459 490 （1966）に揭載された，各国語訳のなかには，越智勇一 (日本学術会議), 飯塚 廣 (東京大学) らによる日本語 訳がある[IJSB，19，3～55(1969)]. Moscuw 会議で 国際ウイルス命名委員会が発足したこともあって, 改正 規約の表題からはウイルスの文字が除かれた。

細菌の植物からの独立と，これに基づく国際細菌命名 規約の根本的な改正といら，細菌学史上の大きな転換期 がそれからまもなく始まるのであるが，これについて は，項を新たにして説明することにする. 


\section{8. 生物の系統における細菌の位置}

さきに述べたように, 18 世紀中期から後期へかけて生 物分類の基礎は固められたが，19 世紀に入って生物体系 の進歩は著しく，J. B. P. A. M. de Lamark(1744〜1829), Ch. Darwin (1809～1882) らの業績を端緒として，細胞 遺伝学や生物系統学へと発展する. その一方では, C. J. Davaine (1950), R. Koch (1876) による炭疽菌の研究, L. Pasteur (1857) による乳酸発酵の研究などによって， 細菌群が生物界へ登場する.19世紀はまさしく細菌学誕 生の世紀であった.

生物を動物と植物の 2 大生物界に区別することは, 古 代から現代にわたって, 自然科学のなかに根強く定着し てきた思想である.しかしながら，系統学者はこの常識に 満足していたわけではない. Bory de Saint-Vincentは, すでに 1822 年, 動物と植物のほかに第三の生物群の存 在を指摘し，系統樹の発表で有名な E. H. Haeckel (1834 〜1919）は，これに Protista（原生生物界，1966）の名 を与えて, 細菌, 菌類, 単細胞藻類, 原生動物, 海綿動 物を含めた. その後, Haeckel は, Protista と植物およ び動物との関係を考虑して, 1894 年, これをProtophyta (原生植物) と Protozoa (原生動物) とに区分し, 生物 進化の方向と系統とを示そうとした。 このらち, Protophyta は, ドイッの植物学者 J. von Sachs (1874)が植物 門として作った名で，後に N.A. Krassil'nikov (1949) が細菌の分類体系に採用してその定義を明確にした。 Bergey's Manual of Determinative Bacteriology で は，第 7 版 (1658) までこの学名が用いられている. Haeckel をはじめとして, 系統学者の共通な考え方は, 生物の個体発生についての観察結果から類推して, 最初 に単細胞生物が出現し, それが各種の多細胞組織体へ進 化したとするもので，それを理論づけるために Protista よりもさらに始原的な生物の存在を想定:して,これに Monera (モネラ) の名を与えたのもやはり Haeckel で あった。

植物の進化が論じられる場合, いつも問題にされるの は，栄養摄取に闒する組織構造と構能である，1826 年， オーストラリフの植物学者, S. L. Endlicherは, 植物の 体制を茎葉体 cormus と葉状体 thallus といら2つの 種類に分けた. 茎葉体というのは, 生活環のなかに茎葉 と維管束の分化が見られる植物体で, 種子植物, シダ植
物、コケ植物のなかの蘚類に見られ，この点からこれら をまとめて茎葉植物 cormophytes と呼ぶ. これに対し て葉状体というのは, 多細胞体ではあるが, 茎葉の区 別が見られず，維管束分化もない植物体で，大部分の菌 類, 藻類, コケ植物のなかの苔類の体組織がこれに当 り、これらををとめて葉状植物 thallophytes と呼ぶ.た だし, 維管束の分化が明瞭なのは, 種子植物とシダ植物 の体組織で, これらは維管束植物とも呼ばれる. 蘚類の 場合は, 維管束の発達はほとんど見られず, 道束と呼ば れる原始的な通道組織を生じる.コケ植物が維管束植物 と葉状植物との中間的段階に位置するものとされるのは， このような理由によるもので, 植物進化の方向は, 葉状 体段階 一茎葉体段階 一維管束段階のようになると考 えられている.

栄養摂取の機能に関して重要な役割を持つのは，葉緑 素とこれに関連する色素群である. これらの色素の存在 は，光合成によって炭酸同化を営むすべての生物，いい かえれば菌類を除く葉状植物と茎葉植物を独立栄養生物 として特色づけ，菌類と，一部原生動物を除くすべての 動物とを，従属栄養生物として区別する理由になってい る（細菌のなかには, 光化学反応や呼吸による化学反応 によって無機栄養もしくは有機栄荃を行ならものが存在 するが，以下に述べる理由によってここでは除外する).

19 世紀から 20 世紀に入ると, 光学顕微鏡の進歩, 電 子顕微鏡の発明などが比較細胞学の研究に著しい進歩と 発展をるたらすことになった，細菌細胞の核相当物質で あるクロマチンを研究していた細胞学者は, それが真菌 や動植物の核および染色体に比べて, 外観, 行動に相違 のあることを認めた，細菌および藍藻では，他の生物の 核のよらな核膜がなく，核原形質が細胞質から隔離され ていないといら事実も明らかにされた．細胞学者は，こ れを核形成に先立つ原始段階を表わするのと判断し，

E. Chatton はこの段階にある細菌と藍藻を原核生物 procaryotes，他を真核生物 eucaryotes と名づけて区別 した [Titres et travaux scientifiques, Seta, Sottino (1937)].これらの生物は DNA，RNA を細胞内にもつ 点で共通するが，さらに低次の生物であるウイルスやフ アージになると，そのどちらか一方に限られる。これら の事実から, Haeckel のモネラにも実在の生物として新 たな定義が与えられることになった. しかしながら， モネラの範囲に原核生物以下を含める意見もあれば，原 


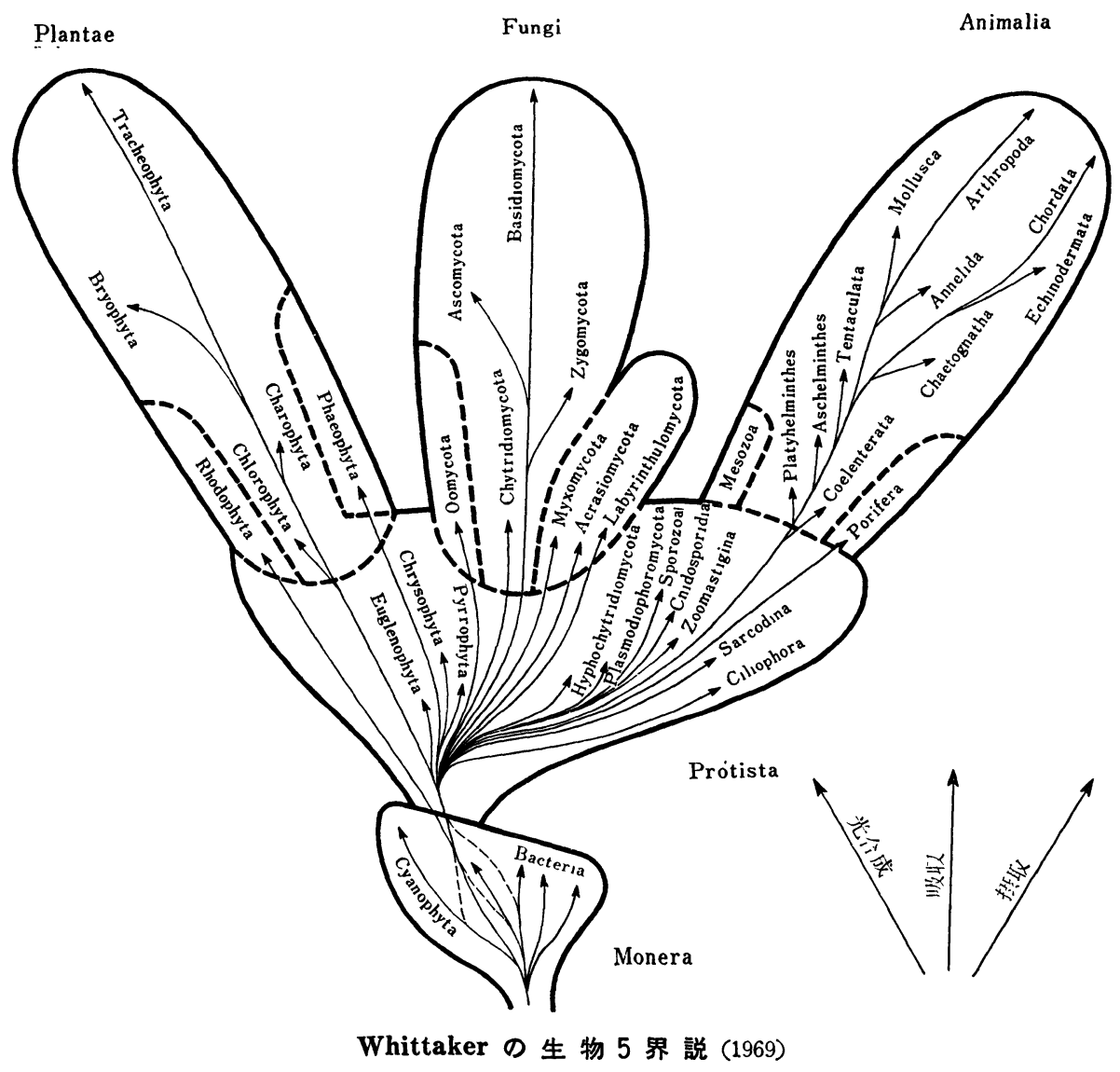

核生物とモネラを区別する見方もあって一定していな い. 図に掲げた R. H. Whittaker の生物 5 界説 [Science, 163，150〜160 (1969)]はその代表的な例である. この 例のように, 生物の進化と系統の観点から, 生物 2 界説 の壁を破ろらとする学説は, 1940 年前後から盛んに発 表されるようになった。

1968 年, R. G. E. Murray は細菌および藍藻のために 原核生物界 Kingdom Procaryotae を提案した. さらに N.E. Gibbons and Murray は，これを細胞壁の性質で 3つの門, Gracilicutes, Firmacutes, Mollicutes に 分類した $[I J S B, 28,1 \sim 6,1978]$.

\section{9. 細菌種の整理に関するレスター会議}

Bergey's Manual of Determinative Bacteriology は, 細菌の命名に関する古今東西の文献を集め, 学名を 体系づけた点で細菌学の研究にはよく利用され, 細菌学 名の手引書として広く知られる. 第1版が出たのは 1923 年であった，編集委員会はその緒言のなかで，本書の編
集方針を説明して，細菌種の進歩総説的紹介にとどま り，決定的分類理論を指示するものでないことを断って いる．したかって，版を重ねるごとに新しい学名と文献 が付け加えられ，同時に分類法も進歩段階に応じて変更 されるといら編集方法が採用され，1958 年には第 7 版を 数兄るに至った. 国際細菌命名委員会の中心的存在であ る Buchanan および Breed が，この Manual の編集 委員会に加わって各版ともとの編集に当ってきたので, 事実上, Manual は国際細菌命名委員会の見解に基づく ものと言ってよい.

1960 年代を挿えで，細菌の命名に対する反省の動き が急速に表面化した. 口火になったのは放線菌について であった，放線菌が各種の抗生物質の生産性において宝 庫的存在であることが明らかにされ，おびただしい種類 の抗生物質が，Streptomyces 属を主とする放線菌で発 表された，特許制度において微生物株の蒿託を義務づけ たのは米国が最も早く 1950 年代に始まり，以後各国に 及んだが，抗生物質生産に関連する新種の正当性は，分 
類学の上だけでなく，特許審査の立場からもしばしば問 題になった. 1958 年, IAMS に放線菌小委員会が設け られ，D. Gottlieb と E. B. Shirlıng を中心に International Cooperative Project for Description and Deposition of Type Cultures of Streptomyces (International Streptomyces Project; ISP) が発足した. 18 カ 国にわたる 40 名以上の放線菌学者が参加し, 13 の国際的 グループに分かれ, Streptomyces, Streptoverticillium に属する種の標準記載（最小標準 minimal standards） を作成するといら協同作業が行なわれ，これらの記載は IJSB, 16, 313 (1966)；17, 315 (1967)；18, 69, 274 (1968)；19，391 (1969)；22，265（1972）に公表され た.

最小標準の作成に当った各グループは, 国籍の異なる 3 名で構成され, 各グループ担当の菌株について各人が 问一の培地と方法で同定作業を行ない, 結果が一致しな ければ別のグループが再度検討するという慎重な方針で 笑施された，実に画期的な企画であった。この間，1962 年, Montreal で開かれた第 8 回国際微生物学会議を機 会汒, 最䘞の国際微生物株保存会議がオタワで開催さ れ, IAMS に微生物株保存分科会 Culture Collection Section*が設けられた. 1966 年の Moscow 会議でも， 放線菌の体系が問題にされた，すなわち，Section，Series など属之種の間の分類階級が体系中に採用されて いるのは細菌のなかでは Streptomyces だけで，その他 の細菌属との間で溝を深めている事実があり, しかも Streptomyces の種には归種または変種としてよいもの まで存在することから，無意味に分類体系を複雑化する ような分類階級は排除したほらがよいといら意見が出た。 こらした討議が引き金になり, 細菌の命名については植 物学への從属性を脱し, 細菌学独自の規約を確立すると ともに, 従来の種名を一挙に整理すべきではないかとい う結論へ発展していった.

国際細菌命名規約の全面改訂と, 忘れ去られて使われ ることのない数多くの種名の排除を榆討するために, 1968 年, 国際細菌命名委員会裁定委員会は英国 Leicester において会議を開き，S.P. Lapage を委員長とする 5 名の命名規約草案起草委員会を発足させた、前記の目 的を達成するための具体的方法が検討され，新規約には

\footnotetext{
*この分科会は 1970 年, 世界微生物株保存連盟 World Federation for Culture Collections と改称.
}

以下の事項を含めることが決まった.

1）将来のある日付を境とし，それ以前の学名につい ては, 学名承認りストApproved List of Bacterial Names を発表し，このリストに揭載された以外の学名 はすべて廃棄する.

2）学名の発表をある範囲の出版物に限定する.

3）培養可能の種は基準株の指定を絶対条件とする. 基準株が実在しないものは，新しく基準株の指定がない 限り承認されない. 基準株の指定と保存の方法.

4）タクンンの最小標準の作成.

5）規約改正に必要な規定の見直し.

1970 年, Mexico 会議において, 国際細菌命名委員会 は, 国際細菌分類命名委員会 International Committee on Systematic Bacteriology (ICSB) と改称し, その下 部機構として専門別の分類学小委員会 Subcommittees on Taxonomyを設けた. Mexico 会議を含めて国際微 生物学会議は微生物学各分野の大集会であったが，以後 は細菌学, 菌学, ウイルス学各分科会ごとに国際会議を 持つことが決まった，その結果, 新しい規約草案は, 1973 年, Jerusalem で開かれた第 1 回国際細菌学会議総 会に提出されて承認を受け, 国際細菌命名規約 (1976 年 改正）として実施に移されることになった.

Bergey's Manual of Determinative Bacteriology 第8版は,こうした過渡的状況のなかで出版された (1974). 第 8 版では, 新しい命名規約と新しい体系の発 表を予定して, 属の上の分類階級の学名を保留し, 種の 記載では基準侏を明記し，基準株の実在が明らかでない ものは区別するといら，従来とは異なる編集方針が採ら れた。

\section{0. 新しい改正規約とその問題点}

過去に発表された学名の整理と統一の必要性は, 生物 学の各分野に共通の問題である. 特に, バクテリアの場 合は，基礎と応用の広い範囲にわたっているから，発表 された学名のなかには，発表されたといら事実があるだ けで，その後第三者によってまったく使用されていない もの，学名の実在を保証する基準株その他の命名基準の 所在が明らかでないもの, 学名に対する記載が不十分で あったり, 命名基準の指定がなくてその実在性に疑義が あるものなど, 問題を含むるのが少なくない. また，学 名発表が数多くの学術雑誌で行なわれてきているから, 
新しく命名を行なら場合, ホモニム(異物同名)を避ける ために必要な文献調査はたいへんな手数である。また， 分類学的研究によって,すでにシノニム（同物異名）と して葬り去られたとみられる学名でも, ホモニムを生じ るので再使用できないというのは，まことに穹屈な話で ある. 過去の学名を清算し, 新しい出発点を設けて出直 すことは, 細菌学にとっても, その進歩のために一度は 必ずくぐらねばならない関門である. 命名基準が培養株 である細菌学名の場合, 保存技術が確立し, 安定してき た現時点において，しかも原核生物界という新しい位置 が与えられた機会にそれが行なわれたとしても，むしろ 当然のことと考えてよいだろら．

1976 年に発効した新しい改正規約は，以上説明したよ うに，かつてない規模と背景を持つものである． 総則, 原則, 規則, 勧告は書き変えられて, その面目を一新し た. 国際細菌分類命名委員会定款も, 従来のものに比べ て全面的に改められた. 付録の一つとして，50 項目を 越える裁定委員会公表見解 Opinions が挙げられている が，いずれる細菌学名に関して採用された意見の記述で, この規約の利用性を高めるのに役立っている.

改正規約の画期性を象徵する最も重要な点の一つは, 学名の出発日, いいかえれば, 優先権の限界が, 従来の 規約では植物の規約と同様に Linné の Species Plantarum の刊行日付である 1753 年 5 月 1 日であったのを, 1980 年 1 月 1 日に変更したことである. この変更のため に, 1979 年以前に発表されたすべての細菌学名のなかか ら, ICSB 分類学小委員会の作業によって選ばれたもの が, 細菌学名承認りストApproved Lists of Bacterial Names として発表された [IJSB，30，225４20(1980)]. 公表された学名は,閒から亜種まで総数約 2,300, 学名の 選定に当って, 命名法上から疑義のあるものや資格の不 十分なものを除いたが，分類学的評価は差し控えたと断 ってある. このリストは，かつての Species Plantarum と同様に細菌学名の出発点となり, 今後の新しい学名の 発表のための基礎になる. したがって，これらの学名は すべて 1980 年 1 月 1 日に発表されたものとして扱われ, 原著論文の発表日付は, 優先権の争いが起こったときだ け尊重される. この場合, 原著論文の発表日付は, その 論文を掲載した刊行物の発行日と定めている.

承認リストの公表によって, 1979 年以前の細菌学名に ついては, 文献調査がきわめて容易になったわけである
が,これに伴って, いくつかの問題が生じている.

1）承認リストに揭載されなかった学名はすすべてそ の存在を無視されることになるから, 今後, もしこれら の学名と同じ名が発表されても，ホモニムとして扱われ ることはない. したがって，特許などの理由で基準株が 公開されなかったため，承認リストに載らなかったよう な場合には, 復活名の手続きがあらかじめ取られていな い限り, 同種または異種の細菌に同一学名が用いられて も優先権を争らことはできない.

2）復活名 revived name に関して, 原著者と関係 のあるなしにかかわらず，その手続きは誰が行なっても かまわないことになっている. この場合, 復活名であっ ても新種の発表と同様に取り扱われるので, 復活名の発 表日付は, 原著の日付むしくは 1980 年 1 月 1 日にさか のぼることにはならない, 復活名は, その手続きを行な ったものが命名者の扱いを受ける. 復活名の元の命名者 名の引用は, 手続きを行なったものの自由意志に委ねら れる，例を挙げて説明すれば，承認リストから除かれて いる Bacillus palustris Sickles \& Shaw 1934 を, かりに Brown が 1982 年に復活させたとする. まず, Brown の論文についていえば, 復活名の表示は, Bacillus palustris sp. nov., nom. rev. または Bacillus palustris (ex Sickles \& Shaw 1934) nom. rev. のど ちらかになる. しかし復活後，第三者がこれを引用する ときは、これを受けて, Bacillus palustris Brown 1982 または Bacillus palustris (ex Sickles and Shaw 1934) Brown 1982 と書くことになる. 断っておくが, 復活名の取り扱いはまったく新しい規則なので, 改正規 約のなかでは暫定規則になっている、いいかえれば，裁 定委員会が提案している段階であって，まだICSB の承 認には至っていない規則といら意味である. しかしなが ら，何らかの反対意見または別の提案が出なければ，正 式な規則になることはほぼまちがいない。

改正規約に打けるもら一つの重要な点は, 細菌学名の 正式な発表機関誌として, IJSB が ICSBによって指定さ れたことである. 他の刊行誌に学名を発表しても, その 事実が IJSB で公表されなければ，学名の正式発表には ならない. 学名発表の日付は IJSB での公表の日付が正 式なるのになる，ただし，優先権の争いが起こったとき は,さきに述べたとおり，原著論文の発表日付が尊重さ れる、命名規約に指定されている発表機関誌は IJSB た 
けであるが，必要があれば，ICSB が他の刉行物を，学: 名に関する正式な機関誌として指定することは可能であ る.

Interntional Streptomyces Projectに始まった，紲菌 分類学過去 20 年のいろいろな動きのすべては, この改 正規約のためにあったかのような観がある. Haeckel が 新しい生物界として Protista を提唱したのは, Darwin が “種の起源”を発表して間もないころであったから， 第三生物界の認識は, 生物系統学とほとんどその歩みを ともにしてきたと考えても差し支えはない. Murray ら
が㝸核生物界を提案し, 定義を与えたのは, その百年後 に当る. 改正規約の発表は, 類似の立場にある菌学の動 向に刺戟を与えずにはおかないだろう。

1980 年 9 月 26 日, 日本学術会議では, IUBS 研究連 絡委員会と同微生物学連絡会の共催で, ICSB 各分類学 小委員会委員の報告を中心に, “細菌の分類と命名に関す るシンポジウム”が開かれた。 また, 改正規約の日本語 版（日本微生物学協会監修）が近く出版されることにな っている.

(拉わり)

プロフィル

S.Gwiazda（スタニスラウ・ギァズ ダ） 1951年生く略歴〉1974年ワルシャ ワ農業大学食品工学部卒業 / 1979年「エ ソドウ濃縮㔻白質の調製とその肉製品混 合物としての機能性」とい5テーマで学 位取得, 現在同大学食品工学部食肉・脂 質研究科講師. 1979 1981年農林水産省 食品総合研究所に留学〈研究テーマと 抱負>ミルク，エンドウ，ルーピン，化 学工学, 機能性, 菜種油製造におけるイ オウ化合物の影響などについて, 学術論 文約 20 , 特許 1 を発表く趣味>釣り，切 手収集, スポーツは万能

木村 修一 (Shuichi Kimura) Vol. 12, No. 8, p. 531

古賀 彰子(Akiko Koga) 炤和24年 2 月 5 日生<略歴>昭和 46 年日本女子大 学家政学部家政理学科卒業 $/ 49$ 年同大学 大学院家政学研究科修士課程 (食物- 栄 養学専攻修了 $/ 55$ 年東北大学大学院農学 研究科博士課程修了/同年同研究科研究 生, 現在にいたる、東北大学医療技術短 期大学部非常勤講師, 農博く研究テーマ と抱負>小腸に限らず，上皮系組織にお ける細胞增生と成熟に対する喿養条件の かかわり方に興昧を持っていますく趣 味>ペートーベンピアノソナタの演奏と 鑑賞 (誰も信じてくれないが……)

桜 井 勝 (Sho Sakurai) 昭和20年 6 月 13 日生<略歴>昭和 44 年東京農工大 学農学部農芸化学科卒業/東京大学大学 院理学系研究科を経て, 昭和56年金沢大 学理学部生物学教室, 現在にいたる.こ の間, 53〜 55年ハーバード大学生物学教 室に留学, 理博く研究テーマと抱負〉昆 虫の脱皮・变態にかかわる内分䎵学
戸嶋 直樹 (Naoki Toshima) 昭和 14 年 1 月 13 日生 $<$ 略歴 $>$ 昭和 37 年大阪大 学工学部応用化学科卒業 $/ 42$ 年同大学大 学院博士課程修了/同年東京大学工学部 工業化学科助手 $/ 48$ 年同講師 $/ 50$ 年同助 教授, 現在にいたるく研究テーマと抱 負 $>$ 工業物理化学 (応用光化学, 合成触 媒化学, 応用錯体化学). 化学の応用に よるエネルギー変換や生体機能の実現が, 化学 (技術) の振興につながると考努 力しているく趣味>テニス, 留学時代は カーリソグを楽しんだ

仲谷 紀男 (Norio Nakaya) 昭和15 年 5 月 29 日生 $<$ 略歴 $>$ 昭和 39 年東京教育 大学農学部農業化学科卒業 $/ 40$ 年農林省 九州農装試験場勤務 $/ 45$ 年同省農業技術 研究所へ転勤, 現在にいたる.この間, 51〜 52年フランス政府給費生として同国 Centre National de Recterches Agronomiques で在外研究く研究テーマと抱 負>有機物が関与する土嘖の物理性を生 物的・化学的観点からも梌颜したい

奈良 省三 (Shozo Nara) 昭和 8 年 10月27日生 <略歷>昭和18年京都帝国大 学農学部卒業後, 同学部助手, 三重青年 師範学校教授, 三重大学農学部助教授を 経て，38年同教授（農芸化学科農産製造 学講座) 現在にいたるく研究テーマと抱 負>澱粉の物性と結晶化度の関連性を明 らかにしたいく趣昧>テニス，野球など 身体を動かすスポーツだが，最近はあま りしない

萛見 恵司 (Keiji Hasumi) 昭和32 年 9 月13日生<略歴>1980年埼录大学理 学部生化学科卒業, 現在東京農工大学大 学院農学研究科修士課程 1 年在学中<砂
究テーマと抱負>コレステロール生合成 阻害物質の検索，コレステロールの代謝 く趣味〉ドライブ, バスケットボール

深海 浩 (Hiroshi Fukami) Vol. 18, No.7, p. 513 参照

A. Rutkowski (アントニー・ラトコ フスキー）1920年生く略歴〉ポツナン 大学卒/1951年学位取得, 現在ワルシャ ワ農業大学食品工学部教授・食品工学研 究所長, ポーランド科学フカデミー会員 く研究テーマと抱負〉油脂ならびにその 関連物質, 油用種子の蛋白質について学 術論文約 200 , 専門論文 150 , 著書 10 , 特 許 8 がある．ポーラ゙ンド内だけでなく， 多くの国際的な科学組織で活唯, また教 育者としてむ活躍し，170 の修士論文， 25 の学位論文作成を指導

山田 哲也 (Tetsuya Yamada) Vol. 18 , No.9, p. 652 参照

合 石 晉 (Susumu Kuraishi) 昭 和 6 年 9 月 3 日生 $<$ 略歴 $>$ 昭和 29 年東京 大学理学部生物学科卒業 $/ 34$ 年同大学大 学院理学系研究科修了, 理博 $/ 39$ 年同大 学教養学部助手, 同助教授を経て53年広 島大学総合科学部教授, 现在にいたる. この間，34〜38年米国ウィスコンシン大 学, アイオワ大学研究員く研究テーマと 抱份>植物ホルモンを中心として, 農学 と理学の間を 5 める仕事を進めたいく趣 味>野外の草花観賞, ただし時間がない、 のであまりやれません. 長男の趣味のサ ボテン栽培をのぞきこんだり，手のりイ ソコと遊ぶことぐらい 